\title{
Diagnostic relevance of peripheral blood immunocytochemistry in hairy cell leukaemia
}

\author{
I Cordone, L Annino, S Masi, E Pescarmona, S Rahimi, A Ferrari, E Giubilei, \\ P Pignoloni, T Faraggiana, F Mandelli
}

\begin{abstract}
Aims-(1) To assess the diagnostic relevance of peripheral blood immunocytochemistry in hairy cell leukaemia (HCL); (2) to compare the immunostaining of bone marrow biopsy specimens with bone marrow and peripheral blood cytospins; (3) to evaluate the sensitivity of the different markers used; (4) to identify the ultrastructural localisation of DBA.44 in HCL variant.
\end{abstract}

Methods-Immunoenzymatic staining procedures, immunoperoxidase and immunoalkaline phosphatase, were used with a panel of monoclonal antibodies directed to HCL associated antigens. Ultrastructural immunostaining was performed using colloidal gold conjugated antibodies.

Results-HCL showed strong cytoplasmic reactivity for $\mathrm{CD22,} C D 25, \mathrm{CD} 103$, DBA.44, $\kappa$, or $\lambda$ light chains. Peripheral blood diagnostic hairy cells were found in all the cases with absolute counts ranging from $0.11 \times 10^{9} / 1$ up to $6.4 \times 10^{9} / 1$ and values increasing with the size of the spleen. A median of $36.5 \%$ of leukaemic cells was found in bone marrow aspirates and $70 \%$ in bone marrow trephine specimens. The monoclonal antibodies CD22 and DBA.44 showed the highest and the lowest percentage of positive hairy cells, respectively; this difference was statistically significant $(p=0.0025)$. Ultrastructural immunolabelling with DBA.44 showed a cytoplasmic membrane localisation of the antigen in one case of HCL variant.

Conclusions-(1) Immunocytochemistry is a useful technique which enhances the accuracy of diagnosis in HCL; (2) peripheral blood immunocytochemistry is recommended because it highlights hairy cells in all cases; (3) CD22 appears to be the most sensitive of the markers tested; (4) ultrastructural analysis is a useful tool in selected cases of HCL variant.

(f Clin Pathol 1995;48:955-960)

Keywords: Immunocytochemistry, hairy cell leukaemia, diagnosis.

Hairy cell leukaemia (HCL) is a chronic B cell lymphoproliferative disorder which accounts for $2 \%$ of all forms of leukaemia in adults. It is characterised by splenomegaly, pancytopenia, bone marrow infiltration, and circulating leukaemic cells with typical cytoplasmic projections. ${ }^{1}$ Recent studies have shown that HCL has a distinctive, unique pattern of antigen expression. $^{2-5}$

Bone marrow aspirates are often unsuccessful in HCL (dry tap) because of a marked increase in reticulin fibres. Diagnostic material is obtained by aspiration only in a minority of patients ${ }^{6}$ and hairy cells are often undetectable in conventionally stained peripheral blood films because of the pancytopenia. Bone marrow trephine is considered the most reliable diagnostic tool for HCL, and immunohistochemistry can help when the presence of an infiltrate is considered equivocal by standard microscopy. ${ }^{78}$

Immunocytochemistry on bone marrow and peripheral blood cytospins could be a useful tool for the detection of hairy cells because morphology and immunophenotype determination can be combined. The aims of this study were to assess the diagnostic relevance of peripheral blood immunocytochemistry in $\mathrm{HCL}$, to compare peripheral blood with bone marrow immunostaining, and to evaluate the sensitivity of the different reagents used. Bone marrow trephine biopsy specimens and bone marrow and peripheral blood cytospins from $23 \mathrm{HCL}$ patients were studied at diagnosis using a panel of monoclonal antibodies directed to HCL associated antigens. As ultrastructural analysis of the cell can be relevant in the differential diagnosis of closely related types of chronic B cell leukaemia, ${ }^{9}$ ultrastructural examination of peripheral blood was conducted in two cases of HCL variant to provide a better morphological evaluation of the leukaemic cells and to identify the localisation of the HCL associated antigen detected by the monoclonal antibody DBA.44.

\section{Methods}

\section{MATERIALS}

Twenty one patients with HCL and two with HCL variant were studied at diagnosis. All subjects included in this study were referred to our institution between July 1992 and June 1994. Nineteen of the patients with classic HCL were male and two were female. Median age was 54 years (range 38-72). Median haemoglobin value was $12.4 \mathrm{~g} / \mathrm{dl}$ (range $7 \cdot 6$ 15.2). The white blood count varied from $1.0 \times 10^{9} / 1$ to $11.2 \times 10^{9} / 1$ (median $2.5 \times 10^{9} /$ 1). The absolute platelet counts ranged from $20 \times 10^{9} / 1$ to $138 \times 10^{9} / 1$ (median $72 \times 10^{9} / 1$ ). According to the spleen size, patients were subdivided for analysis into three groups: (1) patients with no palpable spleen $(n=4)$, (2) patients with splenomegaly $<5 \mathrm{~cm}$ below the 
Table 1 Antibody reagents used in this study

\begin{tabular}{llll}
\hline Antibody & CD No. & Specificity & Source \\
\hline OKB-22 & CD22 & Pan B cell & Ortho \\
L26 & CD20 & B cell & Dakopatts \\
B-ly-7 & CD103 & HCL, T cell subset & Dr S Poppema (Canada) \\
DBA.44 & Non-clustered & HCL, B cell subset & Dakopatts \\
ACT-1 & CD25 & IL-2 Rec $\alpha$ chain & Dakopatts \\
UCHT-1 & CD3 & Pan T cell & Dakopatts \\
Lysozyme & Non-clustered & Monocytes & Dakopatts \\
$\alpha$ Ki67 & Non-clustered & Cycling cells & Dakopatts \\
kappa & & $\kappa+$ B cells & Becton Dickinson \\
lambda & & $\lambda+$ B cells & Becton Dickinson \\
\hline
\end{tabular}

costal margin $(n=9),(3)$ patients with splenomegaly $>5 \mathrm{~cm}$ below the costal margin $(n=8)$.

The two patients with $\mathrm{HCL}$ variant showed marked splenomegaly ( $>5 \mathrm{~cm}$ below the costal margin) and white blood cell counts of $41 \times 10^{9}$ and $11 \times 10^{9}$ cells $/ 1$, respectively.

Normal control bone marrow and peripheral blood cells were obtained from five healthy adults and control bone marrow core biopsy specimens from five patients with normal cellularity. Informed consent for using cells in this study was obtained from all the subjects. The diagnosis of HCL was based on clinical features, cell morphology, immunophenotype, histology, and, in the two cases of HCL variant, by ultrastructural analysis.

\section{PROCEDURES}

Mononuclear cells were isolated from heparinised peripheral blood $(n=23)$ and bone marrow samples $(n=15)$ by Ficoll-Hypaque density gradient centrifugation. Cytospins were prepared with a concentration of $5 \times 10^{4}$ cells per slide, air dried overnight, wrapped in aluminium foil, and stored at $-20^{\circ} \mathrm{C}$ until immunostained. Immunocytochemical labelling was performed by the alkaline phosphataseantialkaline phosphatase (APAAP) and immunoperoxidase (IP) techniques, as previously described. $^{10}$

The antibody reagents used are listed in table 1 . The proportion of positive cells was evaluated by light microscopy with oil immersion (magnification $\times 1000$ ), examining 1000 lymphoid cells per sample. Only cells showing unequivocal morphological appearance of hairy cells (large size, eccentric nucleus, abundant cytoplasm, and characteristic long cytoplasmic villi) were considered to be leukaemic.

Bone marrow core biopsy specimens ( $\mathrm{n}=$ 23) were fixed in $10 \%$ buffered formalin, decalcified in Decal, and embedded in paraffin wax. Five micron thick sections were cut from paraffin wax blocks and stained with Giemsa and Gomori silver impregnation for reticulin fibres. Immunohistochemical studies were performed on paraffin wax sections by the APAAP method $^{11}$ using the monoclonal antibodies L26 (CD20) and DBA.44. Slides were examined by light microscopy and the percentage, pattern of distribution, and morphological characteristics of positive cells were evaluated.

The ultrastructure of two HCL variant cases was examined on peripheral blood mononuclear cells isolated by Ficoll-Hypaque density gradient centrifugation.
For morphological evaluation, the samples were fixed in $2.5 \%$ buffered glutaraldehyde for $1 \mathrm{~h}$, postfixed in $1 \%$ osmium tetroxide $\left(\mathrm{OsO}_{4}\right)$, and embedded in Epon.

For ultrastructural immunostaining, the cells were fixed in $4 \%$ phosphate buffered formaldehyde for 10 minutes, permeabilised with Triton X-100 $(0.25 \%$ in phosphate buffered saline (PBS)) for 5 minutes, and incubated for one hour with CD22 and DBA.44 monoclonal antibodies (diluted 1:5 in PBS). After a second fixation in $2.5 \%$ buffered glutaraldehyde for 10 minutes, samples were incubated for one hour with a $10 \mathrm{~nm}$ colloidal gold conjugated goat anti-mouse antibody (BioCell Research Laboratories) diluted 1:10 in PBS, postfixed in $1 \% \mathrm{OsO}_{4}$, and embedded in Epon. All the incubations were performed at room temperature. Semithin and ultrathin sections were stained with toluidine blue and uranyl acetate, respectively, and observed with a Philips CM10 electron microscope.

Comparison between groups were analysed using the Student $t$ test; linear regression analysis was carried out to study the possibility of a trend across ordered groups.

\section{Results}

EXPRESSION OF HCL ASSOCIATED ANTIGENS IN NORMAL BONE MARROW AND PERIPHERAL BLOOD CELLS

Immunocytochemical staining of cytospins from five normal donors showed a median of $0.3 \%$ (range $0 \cdot 1-0 \cdot 7$ ) CD $103+$ cells and $2 \cdot 2 \%$ (range $2 \cdot 1-2 \cdot 7)$ DBA-44 + cells in the bone marrow, and $0.6 \%$ (range $0 \cdot 2-0.9$ ) $\mathrm{CD} 103+$ cells and $4 \cdot 2 \%$ (range $3 \cdot 2-5 \cdot 5$ ) DBA-44 + cells in the peripheral blood respectively. These were small round lymphoid cells. DBA-44 highlighted short thin cytoplasmic projections in a minority of peripheral blood small lymphocytes. No CD22 +, CD103+, DBA.44+, or CD25 + cells with morphology of hairy cells were found in the bone marrow or peripheral blood of normal individuals.

Bone marrow biopsy speciments from five patients with normal cellularity showed rare scattered DBA.44 positive small lymphocytes. The staining pattern was membrane associated; no cytoplasmic projections were seen.

\section{IMMUNOCYTOCHEMICAL STAINING OF} PERIPHERAL BLOOD AND BONE MARROW CYTOSPINS IN HCL

HCL showed a very consistent immunophenotype. Strong cytoplasmic reactivity of hairy cells for CD22, CD25, CD103, DBA.44, $\kappa$, or $\lambda$ light chains was found in bone marrow and peripheral blood cytospins from the 21 cases of HCL (table 2). Labelled hairy cells were clearly distinguished from non-leukaemic cells and the typical morphology was well preserved (fig 1).

Peripheral blood circulating hairy cells were easily identified by immunocytochemistry in all the cases. Seventy six percent of the patients had $>10 \%$ peripheral blood hairy cells and only one patient had less than $2 \%$ detectable hairy 
Table 2 Percentage of positive cells on cytospin slides. Values are means (SD)

\begin{tabular}{llll}
\hline Antibody & BM aspirate $(n=14)$ & $\mathrm{Pb}(n=21)$ & Cell type \\
\hline CD22 & $40(18)$ & $31(29)$ & Hairy cells \\
CD103 & $35(19)$ & $26(28)$ & Hairy cells \\
DBA-44 & $26(16)$ & $22(25)$ & Hairy cells \\
CD25 & $38(18)$ & $28(27)$ & Hairy cells \\
kappa & $25(28)$ & $10(17)$ & Hairy cells \\
lambda & $16(20)$ & $20(30)$ & Hairy cells \\
CD3 & $31(15)$ & $62(26)$ & T lymphocytes \\
$\alpha$-Lys & Not done & $1 \cdot 4(1 \cdot 3)$ & Monocytes \\
\hline
\end{tabular}

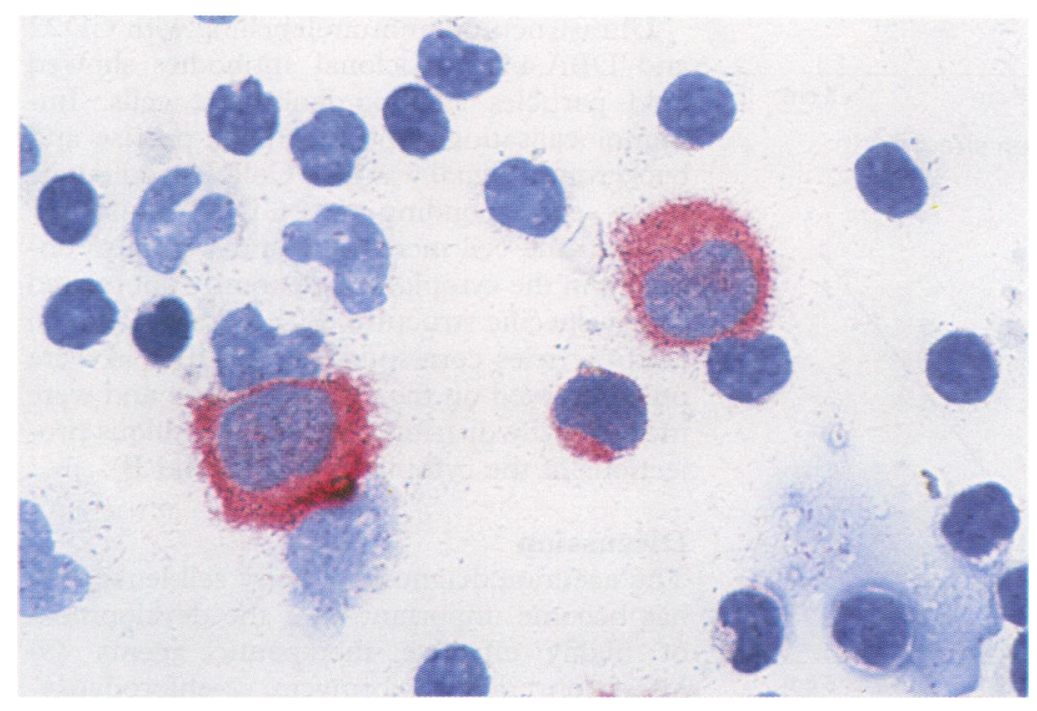

Figure 1 Peripheral blood cytospin immunostaining with APAAP (red cytoplasmic staining) shows two CD22 positive hairy cells with eccentric nucleus and abundant cytoplasm with characteristic villi, and a small CD22 positive B lymphocyte.

cells. The proportion of circulating CD22 positive hairy cells varied from $1 \cdot 32 \%$ to $98 \%$ of mononuclear cells (median $20 \%$ ) with absolute count ranging from $0 \cdot 11 \times 10^{9} / 1$ up to $6.4 \times 10^{9} / 1$. Among the monoclonal antibodies directed against $\mathrm{HCL}$ associated antigens, CD22 accounted for the highest [31(SD 29)\%] and DBA.44 for the lowest [22(25)\%] percentage of positive hairy cells (table 2 ). The difference of sensitivity between CD22 and DBA.44 was statistically significant $(p=0.0025)$. The pattern of immunostaining with DBA.44 showed more intense membrane staining than with CD22. The characteristic projections of the leukaemic cells were strongly highlighted by both antibodies. The percentage of CD103 [26(28)\%] and CD25 [28(27)\%] positive hairy cells was lower than with CD22; however, this difference was not significant. Monoclonal light chain was identified in all patients, including those with a small peripheral blood infiltration. Thirteen cases were $\lambda$ light chain positive $(62 \%)$ and eight were $\kappa$ light chain positive. The typical monocytopenia, with a median of $1 \%$ (range $0 \cdot 1-6 \%$ ) antilysozyme positive monocytes was observed in all cases. A negative cor- relation was found between the percentage of peripheral blood hairy cells and the proportion of CD3 positive $\mathrm{T}$ lymphocytes (table 2 ).

Bone marrow aspirate was unsuccessful (dry tap) in one case and markedly hypocellular in two cases. Diagnostic material was available in $14 / 15$ patients. A proportion of $>10 \%$ hairy cells was found in all the bone marrow samples. The percentage of CD22 + hairy cells in bone marrow ranged from $16 \%$ to $69 \%$ (median $36.5 \%$ ). Similar results were shown with CD103 and CD25. In contrast, DBA.44 accounted for a significant lower percentage of positive hairy cells (table 2 ).

REACTIVITY OF L26 AND DBA.44 IN BONE

MARROW BIOPSIES OF HCL

Bone marrow fibrosis was considered slight $(+)$ in 10 , moderate $(++)$ in seven, and severe $(+++)$ in four cases. In bone marrow trephine biopsy specimens the percentage of L $26+$ hairy cells ranged from $30 \%$ to $90 \%$ of nucleated cells (median $70 \%$ ) (table 3 ). Hairy cells showed intense membrane reactivity with L26 in all the samples. Labelled hairy cells were clearly distinguishable from scattered residual L26+ B lymphocytes because of their wider rim of cytoplasm, hairy projections, and oval, kidney shaped nucleous. L26, with more intense cytoplasmic membrane staining, emphasised the characteristic projections of the leukaemic cells. This assisted in quantifying the extent of bone marrow involvement and was particularly useful in hypocellular and markedly fibrotic samples.

A median of $26 \%$ (range 5-65\%) DBA.44+ leukaemic cells was observed, a proportion significantly lower to the percentage of L26+ cells (table 3). Immunohistochemical labelling gave a more accurate assessment of hairy cells than morphology alone. In two cases with a low degree of interstitial bone marrow infiltration, immunohistochemistry permitted easier identification of the leukaemic population than did morphology. In one case with marked fibrosis, hypoplasia, and scattered CD20 and DBA.44 positive hairy cells in the trephine sample, immunocytochemical staining of bone marrow and peripheral blood cytospins-with $16 \%$ and $5 \%$ hairy cells respectively-was very helpful in confirming the diagnosis of HCL.

Neither the amount of bone marrow infiltration assessed by L26 positivity in trephine biopsy specimens nor bone marrow fibrosis was correlated with the percentage or absolute number of peripheral blood leukaemic cells assessed by CD22 $(r<0 \cdot 1)$. The percentage and absolute number of hairy cells in peripheral blood was found to increase with spleen size. In contrast, no correlation was found between

Table 3 Evaluation of cellularity, L26, DBA.44, fibrosis, and pattern of infiltration in bone marrow biopsy specimens of 21 HCl patients

\begin{tabular}{llllllllllllllllllllll}
\hline Cellularity (\%) & 70 & 80 & 60 & 60 & 70 & 20 & 40 & 90 & 25 & 60 & 60 & 80 & 40 & 50 & 70 & 50 & 70 & 60 & 50 & 25 & 40 \\
L26(\%) & 50 & 80 & 90 & 50 & 80 & 75 & 65 & 65 & 80 & 70 & 65 & 80 & 80 & 50 & 40 & 30 & 85 & 50 & 75 & 45 & 80 \\
DBA.44(\%) & 5 & nd & 5 & 20 & 40 & 10 & 25 & 30 & nd & 20 & nd & 50 & nd & 40 & 20 & 25 & 65 & 5 & 25 & 25 & 10 \\
Fibrosis & + & + & + & + & ++ & + & ++ & ++ & +++ & + & nd & ++ & +++ & +++ & ++ & ++ & ++ & + & +++ & + \\
Pattern & I+D & D & I+D & D & D & I & I+D & I+D & I+D & I & nd & D & I+D & I & I & I & D & D & I & I & I+D \\
\hline
\end{tabular}

$\mathrm{I}=$ interstitial; $\mathrm{D}=$ diffuse; $\mathrm{nd}=$ not done 

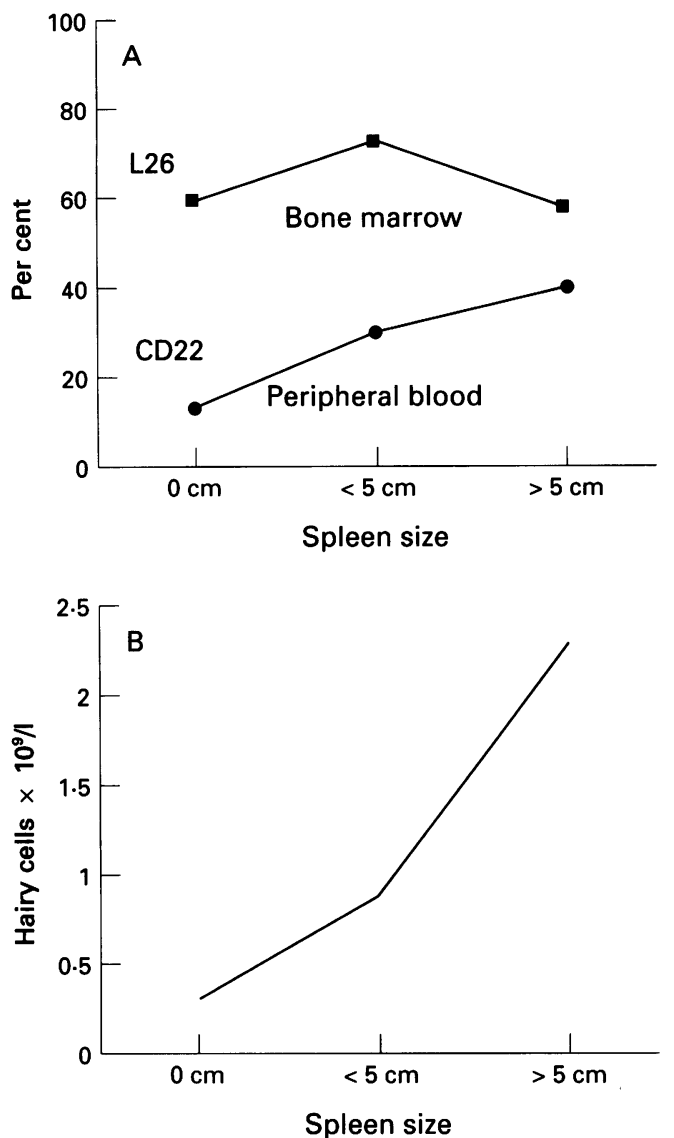

Figure 2 Bone marrow trephine and peripheral blood infiltration by leukaemic cells according to the spleen size. Values represent the mean of the percentage of $C D 22+$ peripheral blood hairy cells and L26+ bone marrow hairy cells $(A)$, and of the absolute number of peripheral blood hairy cells (B) in patients subdivided according to the spleen size.

the size of the spleen and the proportion of bone marrow hairy cells (fig 2 ).

MORPHOLOGY, IMMUNOPHENOTYPE, AND BONE MARROW TREPHINE OF HCL VARIANT

Light microscopic examination of peripheral blood showed a homogeneous population of cells with round nucleus, condensed chromatin, and prominent nucleoli. In one case a prominent nucleolus was present in only a minority of the cells. The cytoplasm was slightly basophilic with fine hairy projections. The proportion of circulating CD22 + hairy cells was $99 \%\left(34.4 \times 10^{9} / 1\right)$ and $89 \%\left(6 \times 10^{9} / 1\right)$ in the two patients. Leukaemic cells were CD22 and DBA.44 positive but CD25 and CD103 negative. Compared with CD22, DBA.44 showed more intense cytoplasmic membrane staining. The percentage of cells in cell cycle $(\mathrm{Ki} 67+)$ was $3.9 \%$ and $0.5 \%$ respectively. Bone marrow trephine biopsy specimens showed minimal involvement by leukaemic cells $(20 \%$ of the total cellularity). The pattern of infiltration was interstitial, with leukaemic cells within the lumen of bone marrow capillaries; reticulin fibres were slightly to moderately increased.

ELECTRON MICROSCOPY OF HCL VARIANT Ultrastructural examination of the two $\mathrm{HCL}$ variant cases showed medium sized cells with round nuclei and heterochromatin condensation at the nuclear periphery. A prominent nucleolus was observed in both cases. The cytoplasm contained numerous mitocondria and free polyribosomes, with strands of long rough endoplasmic reticulum characteristically circumscribing the nucleus. All leukaemic cells showed thin cytoplasmic projections as well as broad based and large buddings with an uneven distribution around the membrane. No ribosome lamellar complexes were observed.

Ultrastructural immunolabelling with CD22 and DBA.44 monoclonal antibodies showed gold particles staining leukaemic cells. Immunolocalisation appeared to be precise and background signal was low. Colloidal gold particles corresponding to CD22 uniformly covered the cell membrane and were also observed in the cytoplasm, apparently not related to any specific structure. By contrast, colloidal gold particles corresponding to DBA.44 were only observed on the cell membrane and were more heavily distributed along the villous projections of the cytoplasm (fig $3 \mathrm{~A}$ and $\mathrm{B}$ ).

\section{Discussion}

The accurate diagnosis of hairy cell leukaemia has become important after the development of highly effective therapeutic agents ( $\alpha$ interferon, deoxycoformycin, 2-chlorodeoxyadenosine) that can induce responses in a high proportion of patients. ${ }^{12-14}$ The simultaneous morphological and immunological evaluation of hairy cells is a powerful tool for the diagnosis of HCL. Immunostaining with monoclonal antibodies is a valid adjunct to conventional morphology in the identification of leukaemic cells in $\mathrm{HCL}^{3-51516}$ Using immunocytochemistry with a combination of antibodies, we regularly identified as few as $1 \%$ hairy cells in peripheral blood and bone marrow samples.

Among the monoclonal antibodies proposed as useful tools for the diagnosis of $\mathrm{HCL}^{2-6}$ we excluded CD11c and HC2 because both strongly react with monocytes and myeloid cells which can be morphologically similar to hairy cells. In our hands, the CD22 monoclonal antibody appears to be the most sensitive marker for the diagnosis of HCL. Unlike the other HCL associated antigens, the majority of hairy cells were CD22 positive and the APAAP staining makes CD22 positive hairy cells easily distinguishable from the small positive normal lymphocytes because of their larger size and cytoplasmic projections.

We also compared immunostaining of hairy cells from different sources. Immunocytochemical staining of peripheral blood cytospins allowed the identification of leukaemic hairy cells, usually overlooked by morphological examination, in all the cases and proved to be helpful in supporting the diagnosis in those patients with minimal bone marrow infiltration. The absolute number of hairy cells was variable ranging from $0.11 \times 10^{9} / 1$ to $6.4 \times 10^{9} / 1$; however, the phenotype was easily characterised, even in those patients with small numbers of circulating leukaemic cells.

The percentage and absolute number of peripheral blood leukaemic cells increased with 


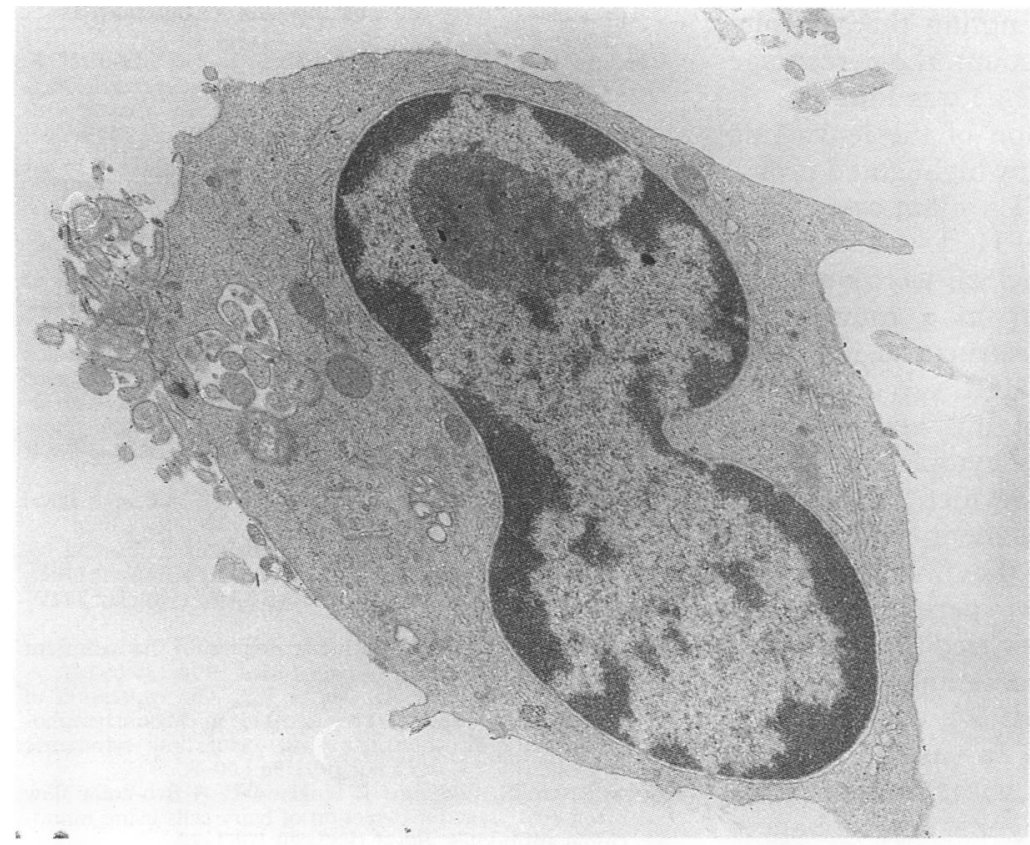

(A)

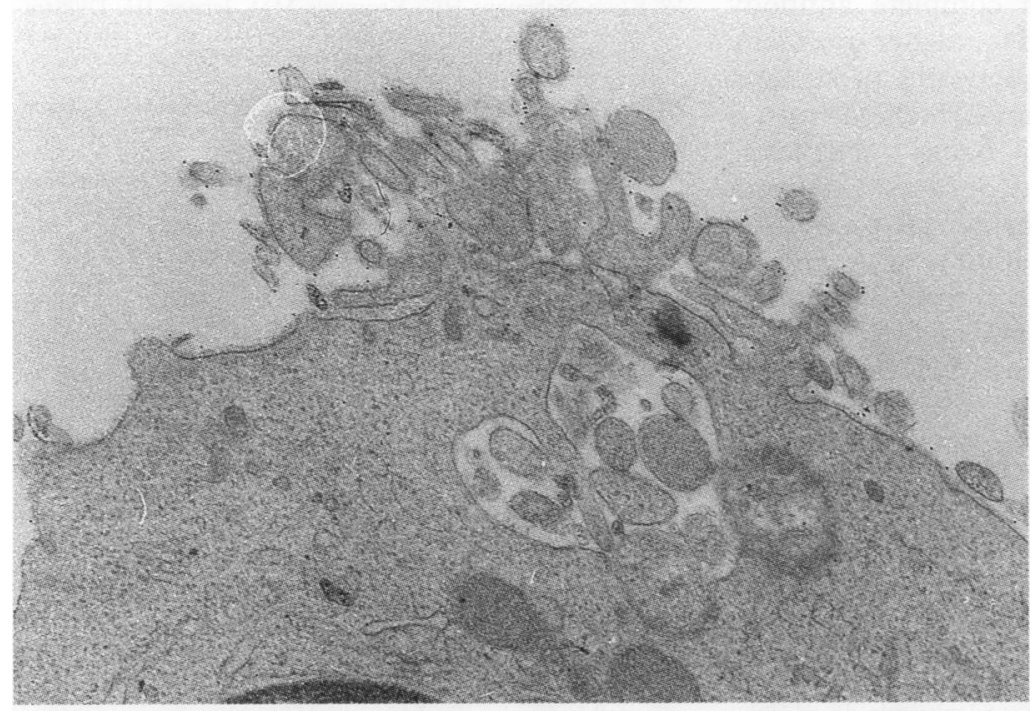

(B)

Figure 3 (A) Ultrastructural immunolabelling of HCL variant shows colloidal gold particles (black dots) corresponding to DBA.44 monoclonal antibodies uniformly decorating the cytoplasmic membrane, with a more heavy distribution along the villous projections of the cytoplasm; $\times 8140$. (B) Colloidal gold particles corresponding to $D B A .44$ (black dots) covering the cytoplasmic villi; $\times 19350$.

spleen size. The small number of patients does not permit any statistical evaluation; the trend, however, supports the hypothesis that the circulating hairy cells originate from the spleen and spread to the peripheral blood.

The antilysozyme antibody was also helpful in the diagnosis of HCL by highlighting the low percentage of monocytes $(1 \%)$, in patients with low peripheral blood leukaemic infiltration.

The bone marrow trephine biopsy is considered the most reliable diagnostic tool for HCL because of the high rate of "dry tap" caused by fibrosis. ${ }^{6}$ On the bone marrow trephine specimens, L26 and DBA.44 were useful in confirming the diagnosis of HCL and estimating the degree of bone marrow infiltration.
These monoclonal antibodies, highlighting the characteristic cytoplasmic projections, were also able to detect scattered individual leukaemic cells in hypoplastic bone marrow. In contrast to a previous report, ${ }^{8}$ the sensitivity of DBA.44 was significantly lower than that of the L26 monoclonal antibodies. Because the small numbers of cells were enough to make cytospins, bone marrow aspiration provided sufficient diagnostic material in 14/15 patients, with a proportion of diagnostic hairy cells greater than $10 \%$ in all the samples. We found a lower percentage of hairy cells in bone marrow cytospins than in bone marrow trephine specimens; the high proportion of CD3 positive lymphocytes on bone marrow cytospins, however, indicates that this difference was due to peripheral blood contamination.

Although HCL is now well established as a B cell leukaemia, its normal counterpart in B cell ontogeny remains undefined. Most investigators agree that $\mathrm{HCL}$ is at a late stage of B cell differentiation. ${ }^{17-19}$ As previously reported $^{20-22}$ we have found a subpopulation of CD103 + lymphocytes in normal peripheral blood. Moreover we have identified a normal peripheral blood subpopulation of DBA.44+ lymphocytes ranging from $3.2 \%$ to $5.5 \%$ of the mononuclear fraction, a minority of which show thin cytoplasmic projections. If a normal counterpart of the hairy cells exists, it may include a subset of DBA-44 + cells.

Immunocytochemistry seems to be promising to monitor treated patients for residual disease after chemotherapy. ${ }^{23-25}$ Using the combination of markers described in this study, we have detected minimal residual disease in bone marrow and peripheral blood of HCL patients considered to be in complete remission by conventional criteria of response to treatment. ${ }^{25}$ DBA.44 has been described as being helpful in the monitoring of residual disease. ${ }^{8}$ This study shows that CD22, CD25, and CD103 monoclonal antibodies have higher sensitivity than DBA.44 in identifying leukaemic hairy cells at diagnosis. Moreover, we found the same difference in sensitivity in the evaluation of minimal residual disease (manuscript in preparation).

HCL variant is an uncommon disorder. ${ }^{2627}$ We found two HCL variant cases out of 23 consecutive HCL patients referred to our institute in a two year period. The distinction of HCL variant from other lymphoproliferative disorders such as splenic lymphoma with villous lymphocytes (SLVL) and prolymphocytic leukaemia (PLL) may be difficult. Defining criteria of these disorders are based on the appraisal of the relevant morphological features as diagnostic combinations of immunological markers, as described for classical HCL, ${ }^{6}$ have not been identified.

We found immunocytochemistry to be helpful in the diagnosis of HCL variant. The combination of hairy morphology, a high proportion of peripheral blood infiltration $(90 \%$ leukaemic cells), and the lack of some of the "HCL associated" antigens (CD25 and CD103 negative), led us to consider the diagnosis of HCL 
variant. It is worthwhile noting that, despite the high white blood cell count, the percentage of cells in cell cycle $(\mathrm{Ki} 67+)$ was low.

Morphological evaluation of the leukaemic cells by electron microscopy highlighted prominent nucleoli in both HCL variant cases. This supported the diagnosis of HCL variant in the case where prominent nucleoli were observed by light microscopy only in a minority of the leukaemic cells. Ultrastructural immunostaining with DBA.44 in HCL variant showed membrane localisation of this antigen. This could explain its intense cytoplasmic membrane staining by immunocytochemistry.

Our results are in agreement with a larger series. ${ }^{5}$ However this is the first study that compared bone marrow, peripheral blood cytospin, and bone marrow trephine specimen immunostaining in the evaluation of the sensitivity of the markers used. We conclude that immunocytochemistry is a useful method which, in combination with routine morphology and histology, significantly enhances the accuracy in diagnosis of $\mathrm{HCL}$ and $\mathrm{HCL}$ variant. $\mathrm{CD} 22$ appears to be a valuable marker, but the application of a complete antibody panel is still recommended for higher specificity and sensitivity in the diagnostic procedure. Peripheral blood immunocytochemistry is always recommended, being diagnostic (HC>10\%) in the majority of cases; long term follow up will establish whether the proportion of peripheral blood infiltration is of prognostic value. In combination with immunocytochemistry, ultrastructural analysis can be a useful tool for the diagnosis of HCL variant.

The authors wish to thank Dr C Vitiello for her assistance in the statistical analysis. We are grateful to Prof S Poppema for samples of the B-ly-7 antibody and to the nurses ML Salvetti and $\mathrm{R}$ Bosu for their excellent technical collaboration. We are also grateful to Prof D Catovsky for the critical revision of the manuscript.

1 Chang KL, Stroup R, Weiss LM. Hairy cell leukemia: current status. Am $\mathcal{7}$ Clin Pathol 1992;97:719-40.

2 Visser L, Shaw A, Slupsky J, Vos H, Poppema S. Monoclonal antibodies reactive with hairy cell leukaemia. Blood 1989; antibodies

3 Mulligan SP, Travade P, Matutes E, Dearden C, Visser L, Poppema S, et al. B-ly-7, a monoclonal antibody reactive with hairy cell leukaemia, also defines an activation antigen on normal CD8 + T cells. Blood 1990;76:959-64.

4 Hassan IB, Hagberg H, Sundstrom C. Immunophenotype of hairy cell leukaemia. Eur $₹$ Haematol 1990;45:172-6.

5 Robbins BA, Ellison DJ, Spinosa JC, Carey CA, Lukes RJ, Poppema S, et al. Diagnostic application of two-color flow cytometry in 161 cases of hairy cell leukemia. Blood 1993; 82:1277-87.

6 Catovsky D, Foa R. Hairy cell leukaemia. In: The lymphoid leukaemias. London: Butterworth, 1990: 156-81.

7 Burke JS. The value of the bone marrow biopsy in the diagnosis of hairy cell leukemia. Am $\mathcal{F}$ Clin Pathol 1978; 70:876-84.

8 Hounieu H, Chittal SM, Al Saati T, De Mascarel A, Sabattini E, Pileri $S$, et al. Hairy cell leukemia. Diagnosis of be hosis of bone marth molveme Haemopathology 1992;98:26-33.

9 Robinson D, Lackie P, Aber V, Catovsky D. Morphometric analysis of chronic B-cell leukemias: an aid to the clasanalysis of chronic B-cell leukemias: an aid to the classification

10 Cordone I, Matutes E, Catovsky D. Characterisation of normal peripheral blood cells in cycle identified by monoclonal antibody Ki-67. F Clin Pathol 1992;45:201-5.

11 Cordell JL, Falini B, Erber WN, Ghosh AK, Abdulaziz $Z$, MacDonald $S$, et al. Immunoenzymatic labelling of monoclonal antibodies using immune complexes of alkaline phosphatase and monoclonal anti alkaline phospatase (APAAP complexes). $\mathcal{F}$ Histochem Cytochem 1984; 32:219-29.

12 Saven A, Piro LD. Treatment of hairy cell leukemia. Blood 1992;79:1111-20

13 Piro LD, Carrera CJ, Carson DA, Beutler E. Lasting remission in hairy cell leukemia induced by a single infusion of 2-chlorodeoxyadenosine. N Engl F Med 1990;322:1117 21.

14 Saven A, Piro L. Newer purine analogues for the treatmen of hairy cell leukemia. $N$ Engl f Med 1994;330:691-7.

15 Miller ML, Fishleder AJ, Tubbs RR. The expression of CD22 (Leu14) and CD11c (Leu M5) in chronic lymphoproliferative disorders using two-color flow cytometric analysis. Am $\mathcal{f}$ Clin Pathol 1991;96:100-8.

16 Kristensen JS, Ellegaard J, Hokland P. A two-color flow cytometric assay for detection of hairy cells using monoclonal antibodies. Blood 1987; 70:1063-72.

17 Anderson KC, Boyd AW, Fisher DC, Leslie D, Schlossman SF, Nadler LF. Hairy cell leukemia: a tumor of pre-plasm cells. Blood 1985;65:620-9

18 Kluin-Nelemans HC, Krouwels MM, Jansen JH, Dijkstra $\mathrm{K}$, van Tol MJD, den Ottolander GJ, et al. Hairy cell leukemia preferentially expresses the IgG3-subclass. Blood 1990;75:972-5.

19 Golomb HM, Davis S, Wilson C, Vardiman J. Surface immunoglobulins on hairy cells of 55 patients with hairy cell leukemia. Am f Hematol 1982;12:397-403.

20 Visser L, Shaw A, Slupsky J, Vos H, Poppema S. Monoclonal antibodies reactive with hairy cell leukemia. Blood 1989 74:320-5.

21 Flenghi L, Spinozzi F, Stein H, Krushwitz M, Pileri S Falini B. LF61: a new monoclonal antibody directed against a trimeric molecule $(150 \mathrm{kDa}, 125 \mathrm{kDa}, 105 \mathrm{kDa})$ associated with hairy cell leukaemia. Br f Haematol 1990; 76:541-9.

22 Falini B, Pileri A, Flenghi L, Liberati $M$, Stein R, Gerli R, et al. Selection of a panel of monoclonal antibodies for monitoring residual disease in peripheral blood and bone marrow of interferon-treated hairy cell leukaemia patients. $\operatorname{Br} \mathcal{F}$ Haematol 1990;76:460-8.

23 Saati TA, Caspar S, Brousset P, Chittal S, Caveriviere $\mathrm{P}$, Hounieu $\mathrm{H}$, et al Production of anti-B monoclonal antibodies (DBB.42, DBA.44, DNA.7 and DND.53) reactive on paraffin-embedded tissues with a new B-lymphoma cell line grafted into athymic nude mice. Blood 1989; 74:2476-85.

24 Hakimian D, Tallman MS, Kiley C, Peterson L. Detection of minimal residual disease by immunostaining of bone marrow biopsies after 2-chlorodeoxyadenosine for hairy marrow biopsies after 2-chlorodeoxyad

25 Cordone I, Annino L, Ferrari, A, Pescarmona E Pacchiarotti A, Giubilei E, et al. Immunocytochemical detection of minimal residual disease in patients with hairy cell leukemia in remission after 2-chlorodeoxyadenosine treatment. Blood 1993;82(suppl 1):562.

26 Sainati L, Matutes E, Mulligan S, de Oliveira MP, Rani S Lampert IA, et al. A variant form of hairy cell leukemia resistant to $\alpha$-interferon: clinical and phenotypic characteristics of 17 patients. Blood 1990;76:157-62.

27 de Totero D, Tazzari PL, Lauria F, Raspadori D, Francia di Celle P, Carbone A, et al. Phenotypic analysis of hairy cell leukemia: "variant" cases express the interleukin-2 receptor b chain, but not the a chain (CD25). Blood 1993; 82:528-35. 